\title{
Human Papillomavirus DNA
}

National Cancer Institute

\section{Source}

National Cancer Institute. Human Papillomavirus DNA. NCI Thesaurus. Code C129664.

The viral DNA that originates from a human papillomavirus. 